PAVEL KOSEK

Masaryk University, Brno

kosek@phil.muni.cz

OLGA NAVRÁTILOVÁ

Masaryk University, Brno

olganav@mail.muni.cz

\title{
RADEK ČECH
}

University of Ostrava

radek.cech@osu.cz

JÁN MAČUTEK

Masaryk University, Brno

Comenius University, Bratislava

jmacutek@yahoo.com

\section{WORD ORDER OF REFLEXIVE SĚ IN FINITE VERB PHRASES IN THE FIRST EDITION OF THE OLD CZECH BIBLE TRANSLATION (PART I)}

Keywords: enclitic, clitic third, heavy constituent constraint, development of the Czech language, Bible translations

\begin{abstract}
The paper deals with the word order of reflexive sě, which is an item on the boundary between a pronominal form and a discrete morpheme. In the first part of the study, we investigate the (en)clitic status of sě in eight books of the oldest complete Czech Bible translation. The analysis focuses only on sě that is dependent on a finite verb: it identifies all possible word order positions of sě in a clause and interprets them in the light of the main competing positions of Czech (en)clitics during the development of the language: 1. the postinitial position, i.e. when an (en)clitic is located after first word/phrase; 2. the contact (verb-adjacent) position, i.e. when an (en)clitic is located immediately before (preverbal position) or after (postverbal position) its syntactically or morphologically superordinate item.
\end{abstract}




\section{Introduction}

This study is one of the first outputs of the authors' research into the development of the word order of prononimal (en)clitics in Old Czech and Early Modern Czech Bibles. The study focuses on pronominal forms which in Modern Czech have the status of stable enclitics: mi, si, ti, mé, sě, těe, ho, mu. ${ }^{1}$

In this study we focus solely on the word order of reflexive sě for the following reasons:

1. it exhibits the highest frequency out of all the investigated pronominal forms,

2. it is a form which developed into a stable (en)clitic during the development of the Czech language,

3. it is on the boundary between a pronominal form and a discrete morpheme (for more details see the section 3: Functional properties and word order of sě in the investigated texts).

We focus solely on the word order of sě as part of a finite verb phrase; we have deliberately omitted cases in which reflexive sě is dependent on an infinitive, participle, (event) nominal or adjective. In these cases, pronominal enclitics occur in so-called noncanonical positions, and their analysis requires a different approach (cf. Toman 2004; Kosek 2011: 32-33, 256-270). We also decided to omit several phenomena connected with (en)clitic word order - particularly (en)clitic groups - due to space constraints.

The primary aims of the study are to investigate:

1. whether the word order of reflexive sě in the investigated texts reflects the original stressed nature of reflexive sé,

2. whether the word order of reflexive sě reflects the competition between postinitial and contact positions of (en)clitics during the development of the language,

3. whether the distribution of postinitial and contact positions is influenced by the length of the initial clausal phrase (or other clausal phrases which precede the (en)clitic),

4. whether the word order of reflexive ser reflects the stylistic differences among the different books of the Bible (or their translators).

\section{The investigated material}

Reflexive ser is investigated in the text of the first edition of the Old Czech Bible translation, specifically in selected books from the Olomouc Bible (Bible olomoucká, BiblOl) and the Litoměřice-Třeboň Bible (Bible litoměřicko-třeboňská, BiblLitTřeb).

\footnotetext{
On the terminology and classification of Czech clitic forms see Avgustinova, Oliva (1997), Junghanns (2002: 134-141), Kosek (2011: 24-33), Karlík, Nekula, Pleskalová (2016: the entry Klitikon). Modern Czech enclitics can (in some circumstances) undergo procliticization, so e.g. Junghanns (2002) considers them to be clitics which are procliticized or encliticized depending on the phonological context. It is not clear whether they had the same property in Old Czech, so we write them in the form of (en)clitics.
} 
The Bible was chosen because it is one of the oldest Old Czech prose texts (more recent poetic texts from the first half of the $14^{\text {th }}$ century were excluded from consideration because verse texts are not a reliable source for researching word order), and also because the results of the analysis can be compared with the situation in later Czech Bible translations, providing an insight into developmental tendencies in the Czech language. ${ }^{2}$

The complete Old Czech translation of the Bible probably dates from the 1350 s (Kyas 1997: 43; Vintr 2008: 1883a). According to Kyas, it was the work of around ten anonymous translators. ${ }^{3}$ No autograph of the translation has survived; the oldest version of the Old Czech Bible has survived in later copies: the Dresden Bible (Bible drážd’anská, 136os), the Litoměřice-Třeboň Bible (Bible litoměřicko-třeboňské, 1411-1414), and the Olomouc Bible (Bible olomoucká, 1417) (Kyas 1997: 57; Vintr 2008: 1883b). However, these copies are not entirely identical to the original version of the text, due to the following factors: 1 . they have not survived in their entirety (in particular the Dresden Bible - see below); 2. the original version of the text was slightly revised in later copies; 3 . some parts of the original text have been replaced by more recent translations, e.g. the Litoměrice-Třeboň and Olomouc Bibles include a different translation of the Gospel of Matthew (known as the Gospel of Matthew with homilies), and the Olomouc Bible incorporates some epistles from the Acts of the Apostles, which were taken from the second edition of the Old Czech Bible translation (Kyas 1997: 42, 61-62; Vintr 2008: 1883b). Unfortunately it is the oldest version of the text - the Dresden Bible - which is the least complete. It was entirely destroyed during the First World War, and only part of the original text has survived in the form of photocopies and copies; Kyas (1997: 37) estimates that only around one-third of the original text has survived.

In view of this situation, we chose the Olomouc Bible as the main text for investigation, i.e. the oldest known complete text of the Old Czech Bible, and the text which forms the basis of a critical edition of the Old Czech Bible as conceived by Kyas (Kyas 1981, 1985, 1988; Kyas, Kyasová, Pečírková 1996; Pečírková et al. 2009). As we have already mentioned above, the investigated form of the reflexive pronoun occurs

2 We are aware that analyzing Old Czech and Early Modern solely on the basis of Bible translations involves a certain degree of risk that the results will be distorted by the specific nature of Biblical language; Bible translators tended to produce quite stylized texts. However, the language used in the first edition of the Old Czech Bible is somewhat different in this regard: according to Kyas (1997: 50) the translators evidently tried to make their translation comprehensible.

3 Kyas (1997: 43) identifies two distinct groups of translators on the basis of the Czech equivalents they used for specific Latin words such as adorare, benedicere, benedictus etc. He states: "The first group included the translator of Genesis; another translator who translated the other books of the Octateuch, the Books of Chronicles, Ezra, Judith and Esther; a third translator translated Job and the other Sapiential Books; and a fourth translated the Gospels. The second group included the author of an idiosyncratic preface to Genesis, who translated the Book of Tobit, the Acts of the Apostles, and possibly also the Books of Kings (unless they were translated by a pupil of his [...] This second group also included the translator of the Books of the Prophets, the translator of the Books of the Maccabees, two translators of the epistles, and finally the translator of the Revelation." The translators' work varied in quality; Kyas (1997: 44) considers the finest translations to be of Genesis, the Sapiential Books, and the Gospels. 
with high frequency, so our research was restricted to selected books from the Old and New Testaments. ${ }^{4}$ We attempted to select books which 1 . as far as possible, differ in their text structure and style, and 2. were the work of different translators, in the view of Kyas (see footnote 3). We made two exceptions to these rules: 1 . We included in our investigation the Acts of the Apostles; as mentioned above, this text is taken from the Litomerrice-Třeboň Bible, meaning that the translation is from the first edition of the Old Czech Bible (the texts in the Olomouc Bible is a later translation from the second edition). 2. We included two Gospels that were probably the work of the same translator, so the corpus contains two texts by the same author and in a similar style. By selecting books that differ in style, and that were translated by different people, we attempted to at least partially compensate for the limitations inherent in analyzing the specific language of Bible texts.

Using the modern edition of the Old Czech Bible, we compiled a corpus of selected transcribed books (Kyas 1981, 1985, 1988; Kyas, Kyasová, Pečírková 1996; Pečírková et al. 2009):

- from the New Testament: The Gospels of Matthew and Luke, the Acts of the Apostles, the Revelation of John;

- from the Old Testament: Genesis (only chapters 1-28), Job, Ecclesiastes (only chapters 1-29) and Isaiah (only chapters 14-40).

Where necessary, we compared the Old Czech translation with the Latin version. According to Kyas, the Old Czech translation was based on a still-unidentified medieval Latin Bible "containing a large number of readings from the so-called Paris copy of the Vulgate." In accordance with Kyas's recommendation, we used "the older edition of the Vulgate based on a 1592 version of the text" (sometimes known as the Clementine Vulgate) (Kyas 1997: 27, 51-52). If necessary, and again in accordance with the approach taken by Kyas, we took into consideration the New Testament text from the edition Nouum testamentum domini nostri Iesu Christi Latine and the Old Testament Biblia sacra iuxta vulgatam versionem ad codicum fidem iussu Pii PP. XI. Librum Genesis (both quoted as BiblVul - see References) which contain medieval variant readings of the Biblical texts.

\section{Functional properties and word order of sě in the investigated texts}

In the investigated texts, the function of reflexive sě oscillates between that of a pronoun and that of a discrete grammatical morpheme which performs various grammatical functions (primarily deagentization and intransitivization) or forms part of the collocative environment of a particular word (for a historical perspective see Šlosar 1981: 141-144 or Pergler 2016; from the perspective of contemporary Czech see Karlík, Nekula, Pleskalová 2016: the entry Reflexivní sloveso, which also lists further literature).

4 We collected a total 2068 occurrences of sè, each of which was annotated (for details see the section Annotation of the examples). 
This range of functions can be viewed as a synchronic witness to a diachronic development which centred around the process of grammaticalization. As part of this process, the originally pronominal form developed into a free morpheme. This functional development in turn influenced the word order of reflexive sě, which developed from an unstable (en)clitic to a stable (en)clitic. This development probably accelerated during the Old Czech period (Trávníček 1956: 147; Šlosar 1967: 252); ${ }^{5}$ as a result, the investigated texts include traces of the original stressed nature of reflexive sě (in all the examples it retains its original pronominal function):

- it is found in prepositional phrases with the prepositions na, mezi, prěed, $v, z a^{6}$

(1) a. I vecě k některým, | ješto sami v sě ufáchu jako spravedlní a jinými hrdáchu,| tento príklad:... BiblOl Lk $18,9^{7}$

who alone NOM.M.PL $_{\text {in }} \mathrm{REFL}_{\mathrm{ACC}}$ trust $_{\text {IMPERFECT.3.PL }}$ as righteous NOM.M.PL $_{\text {PI }}$ and other INSTR.PL $_{\text {despise }}$ IMPERFECT.3.pl

'And to some who trusted in themselves as just, and despised others, he spoke also this parable'

b. Dixit autem et ad quosdam qui in se confidebant tamquam iusti, et aspernabantur ceteros, parabolam istam:... BiblVul

- $\quad$ it can be modified by the pronoun $s a ́ m^{8}$

(2) a. Nebo co jest člověku prospěšno, že ziště vešken svět, | a sám sě ztratí| a sobě zhynutie učiní? BiblOl Lk 9,25

and alone $_{\text {ACC.M.SG }}$ REFL $_{\text {ACC }}$ lose $_{\text {FUT.3.SG }}$

'For what is a man advantaged, if he gain the whole world, and lose himself, and cast away himself?'

b. Quid enim proficit homo, si lucretur universum mundum, se autem ipsum perdat, et detrimentum sui faciat? BiblVul

- $\quad$ it can be coordinated ${ }^{9}$

(3) a. Jsi-li ty syn boží, | uzdrav sám sě i $n y$ ! | BiblOl Lk 23,39

save $_{\text {IMP.2.SG }}$ alone $_{\text {ACC.M.SG }}$ REFL $_{\mathrm{ACC}}$ and $\mathrm{us}_{\mathrm{ACC} . \mathrm{PL}}$

'Aren't you the Christ? Save yourself and us!'

b. Si tu es Christus, salvum fac temet ipsum et nos BiblVulClem

5 Pergler (2016: 104) even claims that this process has still not culminated in contemporary Czech. For more examples see Pergler (2016: 104).

7 A complete translation of the Old Czech examples would lengthen this paper to an unacceptable extent; for this reason, we generally cite one example of a particular phenomenon, with a simple gloss of the relevant parts of examples (the glossed parts of the examples are indicated by a vertical line |). The English Bible translations have been taken from the NET Bible or from the BiblVulClem.

8 For more examples see Pergler (2016: 106).

9 For more examples see Pergler (2016: 104). 
Another trace of the former stressed nature of the reflexive can be found in one example from the Acts of the Apostles (cited as (4a.)), in which the reflexive is positioned immediately after the conjunction $a$ (this is the only such case in the investigated material; in all other cases sě does not follow immediately after the conjunctions $a$, ale, $i$ - see also below $\left.{ }^{10}\right)$ :

(4) a. Jimžto sem otpověděl, jež nenie obyčej Římanóm, by kterého člověka, na něhožto žalují, otsúdili, prvé dokadž by jeho žalobníci při tom nebyli, aby jim otmlúvaje, sobě pomoci mohl $\mid$ a sě očistil z těch vin, | z nichžto jej vinie BiblLitTřeb Acts 25,16 and $\mathrm{REFL}_{\mathrm{ACC}}$ clear $_{\text {PART.PRET.ACT.M.SG. }}$ of this $\mathrm{GEN.F.PL}_{\text {accusations }}$ aEN.F.PL $_{\text {. }}$

'To whom I answered: It is not the custom of the Romans to condemn any man, before that he who is accused have his accusers present, and have liberty to make his answer, to clear himself of the things laid to his charge'

b. Ad quos respondi: Quia non est consuetudo Romanis donare aliquem hominem prius quam is qui accusatur prosentes habeat accusatores, locumque defendendi accipiat ad abluenda crimina BiblVul

In the other cases, however, reflexive sě exhibits characteristics that are typical of (en)clitics:

- it never occurs in clause-initial position (see Table 1 in Part 2)

- it does not follow an interjection

(5) a. |A aj, učinila mi sě stezka hojná| a má řěka bliži sě k moři BiblOl Sir 24,43 and behold become PART.PRET.ACT.F.SG. $_{\text {DAT }}$ REFL $_{\text {ACC }}$ track $_{\text {NOM.F.SG }}$ fertile $_{\text {NOM.F.SG }}$ 'And behold my brook became a great river, and my river came near to a sea'

b. Et ecce factus est mihi tramis abundans, et fluvius meus propinquavit ad mare:... BiblVul

- it does not follow the vocative

(6) a. I povědě panošě: | „Pane, stalo sě jest, | jakož si rozkázal, ale ještě jest prázdné miesto" BiblOl Lk 14,22

Lord $_{\text {VOC.M.SG }}$ happen PART.PRET.ACT.N.SG., $_{\text {REFL }}$ ACC be $_{\text {AUX.PRET.3.SG }}$

'Then the slave said, "Sir, what you instructed has been done, and there is still room"'

b. Domine, factum est ut imperasti,... BiblVul

- it does not follow apposition

(7) a. Jdi pryč, protivníče, nebo psáno jest: | Hospodinu, bohu tvému, budeš šě modliti | a jemu samému slúžiti. BiblOl Mt 4,10

10 See also Trávníček (1956: 148-150). Depending on the context, it would be possible to argue that reflexive sě retains its pronominal status here. 
lord $_{\text {DAT.M.SG }}$ god $_{\text {DAT.M.SG }}$ your $_{\text {DAT.M.SG }}$ be $_{\text {AUX.FUT.3.SG }}$ REFL $_{\text {ACC }}$ pray $_{\text {INF }}$

'Go away, Satan! For it is written: "You are to worship the Lord your God and serve only him"'

b. Scriptum est enim dominum Deum tuum adorabis, et illi soli servies BiblVul

- as has been mentioned, with just one exception it does not follow the conjunctions $a$, ale, $i$

(8) a. I jide déšč, přijidechu vody, viechu větrové|a [na ten dóm] šě obořichu, | i pade,... BiblOl Mt $7,27^{11}$

and upon that ${ }_{\text {ACC.M.SG }}$ house $_{\text {ACC.M.SG }}$ REFL $_{\text {ACC }}$ beat $_{\text {IMPERFECT.3.PL }}$

'And the rain fell, and the floods came, and the winds blew, and they beat upon that house, and it fell'

b. Et descendit pluvia, et venerunt flumina, et flaverunt venti et inruerunt in domum illam, et cecidit, et fuit ruina eius magna BiblVul

Another phenomenon that undoubtedly corresponds with the (en)clitic nature of sé is the elision (haplology, cf. Avgustinova, Oliva 1997: 28) of one out of two occurrences of ser, as illustrated in example (9a.). The example indicates that this phenomenon is found in clauses in which there are two occurrences of sè, each with a different syntactically superordinate item (neslušie š̌ + ženiti sě):

(9) a. Když jest taká věc mezi mužem a mezi ženú, | neslušie sě ženiti...| BiblOl Mt 19,10

NEG1-behove PRS.3.SG REFL $_{\mathrm{ACC}}$ marry $_{\mathrm{INF}}$

'If this is the case of a husband with a wife, it is better not to marry!'

b. Si ita est causa homini cum muliere, non expedit nubere BiblVul

In the other cases, sě occupies the positions of (en)clitics that occur throughout the entire historical development of the Czech language:

\section{Postinitial position}

This position is dominant in cases when the initial phrase in the clause ${ }^{12}$ consists of one word, as illustrated by examples (10a.) and (11a.): ${ }^{13}$

11 We use [square brackets] to indicate phrase boundaries and \{braces\} to indicate emendations or omitted parts of the text.

12 We use the term "phrase" to designate units which are referred to in phrase structure grammar as constituents, i.e. units which consist of two or more clause elements, and whose syntactic function is dictated by the syntactic function of the central word or node (see Karlík, Nekula, Pleskalová 2016: the entry Složka).

13 A variant on postinitial position is found in some cases (illustrated, for instance, in examples (8a.) or (26a.)), in which the coordinating conjunctions $a$, ale, $i$ are positioned at the beginning of the clause. This causes the (en)clitic to cliticize after the word/phrase that follows these coordinating conjunctions. 
(10) a. Nebo jsú kleštěnci, | [ješto sú sěz života mateře tak narodili,]... | BiblOl Mt 19,12 who be AUX.PRET.3.PL $_{\text {REFL }}$ ACC $_{\text {from womb }}$ GEN.M.SG mother $_{\text {GEN.M.SG }}$ so born PART.PRET. $_{\text {PR. }}$ ACT.M.PL

'For there are eunuchs, who were born so from their mother's womb'

b. Sunt enim eunuchi, qui de matris utero sic nati sunt BibilVul

(11) a. Tehda sě otevřě chrám boží v nebi... BiblOl Rev 11,19

then $\mathrm{REFL}_{\mathrm{ACC}}$ open $_{\mathrm{FUT.3.SG}}$ temple $_{\text {NOM.M.SG }} \operatorname{god}_{\mathrm{ADJ.POS.NOM.M.SG}}$ in heaven $\mathrm{L}_{\text {LOC.N.SG }}$ 'Then the temple of God in heaven was opened'

b. Et apertum est templum Dei in coelo BiblVul

If an embedded clause or a transgressive phrase precedes the matrix clause, the (en)clitic follows the clause element that is positioned after this anteposed clause/ phrase, as shown in the following examples (12a.) and (13a.):

(12) a. A [když uslyšěsta hlas hospodina boha chodiece po polednie hodině v ráji,]|skry sě Adam i jeho žena před obličejem hospodina boha prostřěd dřěva rajského BiblOl Gen 3,8

hide $_{\text {AORIST.3.SG }}$ REFL $_{\text {ACC }}$ Adam $_{\text {NOM.M.SG }}$ and his NOM.F.SG $_{\text {wife }}$ NOM.F.SG $_{\text {from face }}$ INSTR.M.SG $_{\text {I }}$ lord $_{\text {GEN.M.SG }}$ among tree ${ }_{\text {GEN.N.SG }}$ paradisal $_{\text {GEN.N.SG }}$

'And when they heard the voice of the Lord God walking in paradise at the afternoon air'

b. Et cum audissent vocem Domini Dei deambulantis in paradiso ad auram post meridiem, abscondit se Adam et uxor eius a facie Domini Dei in medio ligni paradisi BiblVul

(13) a. [Přišedše ke mně,] | hanbú sú sě zastyděli|BiblOl Job 6,20

shame $_{\text {INSTR.F.SG }}$ be $_{\text {AUX.PRET.3.PL }}$ REFL $_{\text {ACC }}$ feel-shame PART.PRET.ACT.M.PL $_{\text {PI. }}$

'they arrived there, but were disappointed'

b. venerunt quoque usque ad me, et pudore cooperti sunt BiblVulClem

If the initial phrase is a multi-word phrase (i.e. consisting of two or more words), in Old Czech the (en)clitic occurs in two different variants of the postinitial position: 1. after the first word, despite the fact that it thereby divides the phrase into two parts as illustrated in example (14a.) or the clause $[\text { hřiech }]_{1}$ sé $[j i c h]_{1}$ obtiežil in example (17a.) (in accordance with Halpern's 1995 nomenclature we designate this position as $2 \mathrm{~W}$ ); 2 . at the end of a multi-word initial phrase, as shown in example (15a.) (again we use Halpern's nomenclature 2D):

(14) a. To oni uslyšěvše, | [s velikú $]_{1} \underline{s}_{2}{ }_{2}[\text { náhlostí }]_{1}$ rozhnèvali ${ }_{2} \mid$ i zavolali sú řkúc:... BiblLitTřeb Acts 19,28 
with big $_{\text {INSTR.F.SG }}$ REFL $_{\text {ACC }}$ rage $_{\text {INSTR.F.SG }}$ get-angry PART.PRET.ACT.M.PL $_{\text {. }}$

'When they heard this they became enraged and began to shout'

b. His auditis, repleti sunt ira, et exclamaverunt dicentes:... BiblVul

(15) a. A inhed biechu veliké blýskoty a hlasové a hř́manie |a [tak velmi] sě zemè potřásla, |jehožto třěsenie nikda nebylo tak velikého, jakž sú lidé počěli na světě bydliti BiblOl Rev 16,18

and so big $\mathrm{REFL}_{\mathrm{ACC}}$ earth $\mathrm{NOM.F.SG}_{\text {quake }}$ PuRT.PRET.ACT.F.SG

'And there were lightnings, and voices, and thunders, such an one as never had been since men were upon the earth, such an earthquake, so great'

b. Et facta sunt fulgura, et voces, et tonitrua, et terree motus factus est magnus, qualis numquam fuit ex quo homines fuerunt super terram... BiblVulClem

\section{Contact position}

Besides the postinitial position, an (en)clitic can also occur in contact position, i.e. immediately adjacent to its syntactically/morphologically superordinate item. ${ }^{14}$ This word order position of (en)clitics has parallels in other Slavic languages (e.g. Bulgarian, Macedonian). In Russian it even enabled a process of grammaticalization to occur, as the reflexive became part of the verb form itself. In historical Czech, (en)clitics in contact position can be found 1. after their regents (i.e. postposition or postverbal position), as shown in example (16a.), in the clause Volánie Sodomských a Gomorrejských rozmnožilo sě jest in example (17a.) or in the clause [Slúpové nebeští] třasú sě in examle (20a.); 2. before their regents (i.e. anteposition or preverbal position), as shown in examples (18a.) and (19a.). If the form of the regent verb is analytical, it may happen that the (en)clitic is positioned between two stressed verb forms, i.e. an auxiliary and a non-finite form of a lexical verb, e.g. budeš sě modliti in example (7a.) (it is debatable which of these two verb components should be considered the regent of the (en)clitic, so in such cases we refer to the (en)clitic position as interverbal position).

(16) a. Ale [mládenečky] hnětla sě v životě jsúce BiblOl Gen 25,22

but children INSTR.M.PL $_{\text {struggle }}$ PART.PRET.ACT.F.SG REFL $_{\text {ACC }}$ in womb LOC.M.SG $_{\text {being }}$ PART. PRS.ACT.NOM.PL

'But the children struggled in her womb'

b. Sed collidebantur in utero eius parvuli BiblVulClem

(17) a. [Volánie Sodomských a Gomorrejských] rozmnožilo sě jest a hřiech sějich obtiežil velmi přieliš BiblOl Gen 18,20

14 For the sake of simplicity, we classify words which are grammatically/syntactically superordinate to pronominal and verbal (en)clitics as clitic regents (Toman 2004). A similar approach was taken by Lešnerová (2002: 325); she considers these relations to be cases of morphological and syntactic dependency. 
outcry $_{\text {NOM.N.SG }}$ sodom $_{\text {ADJ.GEN.M.PL }}$ and gomorrha ADJ.GEN.M.PL $_{\text {multiply }}$ PART.PRET.ACT.N.SG $_{\text {P. }}$ REFL $_{\text {ACC }}$ be $_{\text {AUX.PRET.3.SG }}$ and $\sin _{\text {NOM.M.SG }}$ REFL $_{\text {ACC }}$ their $_{\text {NOM.M.SG }}$ burden $_{\text {PART.PRET. }}$ ACT.M.SG exceedingly grievous

'The cry of Sodom and Gomorrha is multiplied, and their sin is become exceedingly grievous'

b. Clamor Sodomorum et Gomorree multiplicatus est, et peccatum earum adgravatum est nimis BiblVul

(18) a. A ty poslúchaj mé rady a vstana beřiž sě k Labanovi, bratru mému, do Aram a tu prěěbudeš několik časóv s ním, | [ažt] [zatiem] sě uspokojí hněv bratra tvého | BiblOl Gen 27,43-44

until meanwhile REFL $_{\text {ACC }}$ subside $_{\text {FUT.3.SG }}$ rage $_{\text {NOM.M.SG }}$ brother $_{\text {GEN.M.SG }}$ your $_{\text {GEN.M.SG }}$ 'Now then, my son, do what I say. Run away immediately to my brother Laban in Haran. Live with him for a little while until your brother's rage subsides'

b. ... donec requiescat furor fratris tui ... BiblVul

(19) a. Vše, cožkoli die Sára, poslušen bud’jie, | [nebo][po Izákovi][tvé siemě] sě rozplodí BiblOl Gen 21,12

because after Isaac LOC.M.SG $_{\text {your }}$ NOM.N.SG $_{\text {seed }}$ NOM.N.SG $_{\text {REFL }}$ ACC $_{\text {reproduce }}$ FUT.3.SG 'Do all that Sarah is telling you because through Isaac your descendants will be counted'

b. ... quia in Isaac vocabitur tibi semen ... BiblVulClem

It is clear from the cited examples (16a.) - (19a.) that an (en)clitic in contact position accompanies its regent in various clausal positions. In order to describe the functioning of (en)clitics in these positions, we classify the positions as follows: medial postverbal position (example (16a.), medial preverbal (example (18a.)), prefinal (example (19a.)), and final (the clause Volánie Sodomských a Gomorrejských rozmnožilo sě jest in example (17a.) or the clause [Slúpové nebeští] třasú sě in ex. (20a.)).

\section{Medial isolated position}

In these cases, the (en)clitic is positioned in the middle of the clause, without immediate contact with its syntactically/morphologically superordinate item (however in these cases it is always positioned to the left of its regent - Franks, King 2000: 112-114). This position, illustrated by the clause jeho silú náhle sě mořě zbierají in example (20a.), occurs with very low frequency both in historical and contemporary Czech, usually performing various discursive or pragmatic functions (Franks, King 2000: 115-117; Kosek 2011: 38).

(20) a. Slúpové nebeští třasú sě a bojie sě jeho vóle, | [jeho silú][náhle] sě [mořě] zbierají... | BiblOl Job 26, 11-12

his $_{\text {INSTR.F.SG }}$ power $_{\text {INSTR.F.SG }}$ suddenly REFL $_{\text {ACC }}$ sea $_{\text {NOM.N.SG }}$ gather $_{\text {PRS.3.PL }}$ 
'The pillars of heaven tremble, and dread at his beck. By his power the seas are suddenly gathered together'

b. In fortitudine illius repente maria congregata sunt, et prudentia eius percussit superbum BiblVulClem

As has been mentioned above, there are substantial differences between frequencies of occurrence in the various positions in historical Czech. In the following part of the study, we attempt to identify these differences in the investigated Bible texts, and then - based on quantitative data analysis - to interpret these differences. The analysis does not address the few cases - demonstrated here in examples (1a.) (4a.) - in which the reflexive retains traces of its stressed nature.

\section{Conclusion}

In the analyzed texts from the first edition of the Old Czech Bible, reflexive ser retains traces of its original stressed nature, but in the large majority of cases it behaves like an (en)clitic. This can be understood as a symptom of the acceleration of the process of transformation of reflexive sě into a stable (en)clitic in Old Czech. Like other Old Czech verbal and pronominal (en)clitics, the reflexive also occupies several clausal positions, which reflect the competition between postinitial and contact position in Old Czech and Early Modern Czech (en)clitics. The frequencies of the particular positions are analyzed in Part II of this paper.

\section{Acknowledgement}

This study was supported by the project Development of the Czech pronominal (en)clitics (GAČR GA17-02545S).

\section{Abbreviations of Biblical books}

Acts $=$ Acts of the Apostlees; Gen = Genesis; Job = Job; Lk = Gospel of Luke; $\mathbf{M t}=$ Gospel of Matthew; Rev = Revelation; Sir = Sirach

\section{References}

Avgustinova T., Oliva K. 1997. On the nature of the Wackernagel position in Czech. - Junghanns U., Zybatow G. (eds.). Formale Slavistik. Frankfurt am Mein: 25-47.

BiblLitTřeb = Litoměřice-Třeboň Bible (Bible litoměřicko-třeboňská). See Kyas 1981, 1985, 1988, 1997; Kyas, Kyasova, Pečírková 1996; Pečírková et al. 2009. 
BiblOL = Olomouc Bible (Bible olomoucká). See Kyas 1981, 1985, 1988, 1997; Kyas, Kyasova, Pečírková 1996; Pečírková et al. 2009.

BiblVul = (1) Wordsworth J., White H.J. (eds.). 1889-1898, 1954. Nouum testamentum domini nostri Iesu Christi Latine. [vols. 1-3]. Oxford; (2) Biblia sacra iuxta vulgatam versionem ad codicum fidem iussu Pii PP. XI. Librum Genesis. [vols. 1-11]. 1926-1957. Rome.

BiblVulClem = Clementine Vulgate. [available at http://vulsearch.sourceforge.net].

Franks S., King T.H. 2000. A handbook of Slavic clitics. Oxford.

Halpern A. 1995. On the placement and morphology of clitics. Stanford.

Junghanns U. 2002. Klitische Elemente im Tschechischen: eine kritische Bestandaunahme. Daiber T. (ed.). Linguistische Beiträge zur Slavistik IX. München: 117-150.

Karlík P., Nekula M., Pleskalová J. (eds.). 2016. Nový encyklopedický slovník češtiny. Praha.

Kosek P. 2011. Enklitika v češtině barokní doby. Brno.

Kyas V. (ed.). 1981. Staročeská bible drážd’anská a olomoucká: kritické vydáni nejstaršího českého prekladu bible ze 14. století. I. Evangelia. Praha.

Kyas V. (ed.). 1985. Staročeská bible drážd’anská a olomoucká: kritické vydáni nejstaršího českého překladu bible ze 14. století s částmi Bible litoměřicko-třeboňské. II. Epištoly. Skutky apoštolì. Apokalypsa. Praha.

Kyas V. (ed.). 1988. Staročeská bible drážd’anská a olomoucká: kritické vydáni nejstaršího českého překladu bible ze 14. století. III. Genesis-Esdráš. Praha.

Kyas V. 1997. Česká Bible v dějinách národního písemnictví. Praha.

Kyas V., Kyasová V., Pečírková J. (eds.). 1996. Staročeská bible drážd’anská a olomoucká: kritické vydáni nejstaršího českého překladu bible ze 14. století. IV. Tobiáš-Sirachovec. Padeborn.

Lešnerová Š. 2002. Postavení příklonky „se“v textu Kryštofa Haranta „Cesta z Království českého... do Země svaté...." - Hladká Z., Karlík P. (eds.). Čeština - univerzália a specifika 4. Brno: 325-327.

NET Bible = New English translation. [available at http://www.bible.org/netbible/index.htm]. Pečírková J. et al. (eds.). 2009. Staročeská Bible drážd’anská a olomoucká s částmi Prorokủ rožmberských a Bible litoměřicko-třeboňské. V/1 Izaiáš-Daniel, V/2 Ozeáš-2. kniha Makabejská. Praha.

Pergler J. 2016. K otázce tzv. akuzativního se v češtině: pohled (nejen) diachronní. - Slovo a slovesnost 77.2: 102-122.

Šlosar D. 1967. Poloha enklitik jako kritérium k hodnocení staročeské interpunkce. - Listy filologické 91.3: 251-258.

Šlosar D. 1981. Slovotvorný vývoj českého slovesa. Brno.

Toman J. 2004. Ertlova diskuse českých klitik. - Hladká Z., Karlík P. (eds.). Čeština - univerzália a specifika 5: 73-79.

Trávníček F. 1956. Historická mluvnice česká 3. Skladba. Praha.

Vintr J. 2008. Bible (staroslověnský překlad, české překlady). - Merhaut L. et al. (eds.). Lexikon

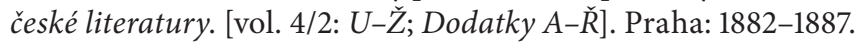

